\title{
Deductio ad absurdum: \\ CEOs donating their own stock \\ to their own family foundations
}

\author{
David Yermack \\ Professor of Finance \\ NYU Stern School of Business \\ 44 West $4^{\text {th }}$ Street, Suite 9-160 \\ New York, NY 10012 \\ dyermack@stern.nyu.edu
}

September 2008

\begin{abstract}
I study large charitable stock gifts by Chairmen and CEOs of public companies. These gifts, which are not subject to insider trading law, often occur just before sharp declines in their companies' share prices. This timing is more pronounced when executives donate their own shares to their own family foundations. Evidence related to reporting delays and seasonal patterns suggests that some CEOs backdate stock gifts to increase personal income tax benefits. CEOs' family foundations hold donated stock for long periods rather than diversifying, permitting CEOs to continue voting the shares.

I appreciate helpful comments from Stephen Choi, Henrik Cronqvist, Bjorn Jorgensen, Simon Lorne, Thomas Noe, Mark Seasholes, Jack Siegel, and seminar participants at Arizona State University, the University of Arizona, Cornell University, Erasmus University Rotterdam, Helsinki Swedish School of Economics, INSEAD, New York University, Oxford University, the University of Pennsylvania, the University of Zurich, and the Gerzensee European Summer Symposium on Financial Markets. Part of this research was completed while I was a visiting professor at Erasmus University Rotterdam.
\end{abstract}




\section{Deductio ad absurdum: \\ CEOs donating their own stock to their own family foundations}

\section{Introduction}

Successful business executives often have noteworthy second careers as philanthropists. Examples have spanned the history of American industry, from John Jacob Astor, Andrew Carnegie, and John D. Rockefeller through Warren Buffett, Ted Turner, and Bill Gates. For tax reasons, modern donors often finance their good works by giving away appreciated shares of stock. Under U.S. tax law, charitable gifts of stock allow the donor to obtain a personal income tax deduction for the market value of the shares, while also nullifying the capital gains tax that would be due if the shares were sold.

Unlike open market sales, gifts of stock are generally not constrained by U.S. insider trading law, and company officers can often donate shares of stock to charities at times when selling the same shares would be prohibited. This exemption has evolved from a combination of federal caselaw, prosecutorial indifference, and recent amendments to SEC rules (Sulcoski, 1989). This paper explores whether executives exploit the insider trading gift loophole to make well-timed charitable donations of stock in advance of price declines, a strategy that would allow the donors to use their access to inside information to obtain personal income tax benefits. 
I focus upon Chairmen and CEOs of U.S. public companies who establish private family foundations and then make large contributions to these foundations out of their personal holdings of company shares. Because these donors generally controls the entities on either side of these transactions, while also having private information about the future prospects of their companies, one might expect well-timed donations to private family foundations to be relatively easy to accomplish and document.

I study a sample of 150 stock gifts worth at least $\$ 1$ million by public company Chairmen or CEOs to their own family foundations. Identifying this sample requires crosschecking stock gifts reported by executives on SEC Form 4 and Form 5 filings against donations disclosed by private foundations on annual IRS Form 990-PF filings. The 150 large gifts in my sample are made by 89 different executives between mid-2003, when the SEC established electronic filing requirements for stock transfers, and the end of 2005. The aggregate value of the gifts, about $\$ 670$ million, represents nearly one-quarter of all stock gifts made by all public company Chairmen and CEOs for charitable purposes during this time period.

Consistent with their exemption from insider trading law, I find a pattern of excellent timing of Chairmen and CEOs' large stock gifts to their own family foundations. On average these gifts occur at peaks in company stock prices, following run-ups and just before significant price drops. The price path of the underlying company stocks forms an inverted V-shape over two month period centered around the reported gift date, with the stock rising and then falling by an abnormal 3\% and peaking exactly on the reported gift date. For comparison purposes I look at stock gifts by Chairmen and CEO to all other recipients besides family foundations. These other transfers are also well timed, as they occur at local maximums in company stock prices, but 
the typical price decline after these gifts is significantly less pronounced than for gifts to CEOs' own family foundations.

I explore two explanations for the good timing of CEOs' family foundation stock gifts. One clear possibility is a variation on classical insider trading. CEOs might use their knowledge of inside information to donate shares at opportune times in order to increase their personal income tax benefits. A variety of tests give some support for the hypothesis that CEOs time their gifts based on inside information. For instance, a few CEOs make gifts of stock just before adverse quarterly earnings announcements, a time at which company "blackout" periods would almost always prohibit open market sales (Bettis, Coles and Lemmon, 2000). Other CEOs delay stock gifts until just after positive quarterly earnings announcements.

A second explanation is that CEOs' stock gifts might be backdated to local maximum points in company stock price histories, again in a way that would increase the personal income tax benefits to the CEO. Such backdating would require coordination between the foundation's trustees (generally the CEO and his family) and the company's stock transfer department (which reports, at least indirectly, to the CEO). This sort of collusion is not difficult to imagine given the abundant evidence of backdating of executives' stock compensation that has emerged since 2006 in academic studies (Heron and Lie, 2007) and investigations by the IRS, SEC, and Department of Justice. Stock gift backdating, if followed by the filing of a personal tax return claiming a charitable gift deduction, would likely represent tax fraud in violation of IRS rules that look to the actual transfer date for determining a stock gift's value. ${ }^{1}$

\footnotetext{
${ }^{1}$ IRS Publication 561, "Determining the Value of Donated Property," rev. April 2007, p. 2, gives the rules for identifying the date of a stock contribution in order to value it for tax purposes. If a stock certificate is delivered physically to a charity, the date of delivery is the valuation date. If it is mailed, valuation occurs on the date of mailing. Assuming that most CEO-donors follow the modern practice of arranging the stock transfer electronically through a bank
} 
Tests used to infer the backdating of executive stock option awards yield results consistent with the backdating of CEOs' family foundation stock gifts. For instance, I find that the apparent timing of certain subsamples of family foundation stock gifts improves as a function of the elapsed time between the purported gift date and the date on which the required stock gift disclosure is filed by the donor with the SEC. This associated between reporting lags and favorable gift timing does not hold for CEOs' stock gifts to other recipients. Stock gifts of all types, including family foundation gifts, are also timed more favorably if they are larger and if they occur in months other than December, when many tax-driven charitable contributions ordinarily take place.

These results suggest an odd juxtaposition of motives on the part of corporate executives who donate stock. While nominally transferring part of their fortunes to charitable foundations for civic purposes, many appear simultaneously to exploit gaps in the regulation of insider trading or even to backdate their donations to increase the value of personal income tax benefits. The results loosely parallel a series of older tax fraud cases related to donations of artworks to museums, in which the recipients were found to have colluded with donors to generate inflated appraisal values that could be used to claim larger income tax deductions (Speiller, 1980). ${ }^{2}$

or broker, "the date of the contribution is the date the stock is transferred on the books of the corporation," according to the IRS. This language is somewhat elastic, as it does not appear to require the corporation to record a transfer in a timely way and may even accommodate retroactive dating of stock transfers. However, other bodies of law dealing with fraudulent accounting would likely require company bookkeepers to record stock transfers accurately.

${ }^{2}$ Probably the most famous case of a fraudulently backdated charitable gift came to light in the 1974 Congressional investigation of President Richard M. Nixon's personal income tax returns. While serving as president, Nixon donated his vice presidential papers from the Eisenhower administration to the National Archives and claimed that the gift had occurred in early 1969 , entitling him to a $\$ 576,000$ tax deduction. Subsequent Congressional testimony by a federal archivist revealed that the true date of the gift was approximately one year later, after an intervening change in federal law had made the deduction worthless. See Patricia Sullivan, "Mary Livingston: Spotted Illegal Nixon Tax Move," The Washington Post, March 25, 2007, C1. Nixon, who denied knowledge of the backdating, was ordered to pay restitution to the U.S. Treasury. His tax advisor pleaded guilty to fraud and received a four month jail sentence. See Eric Pace, "Edward Morgan, 61, Nixon Aide Convicted in Tax Fraud Case," The New York Times, August 20, 1999. 
Data in the paper also cast a long shadow upon the increasingly popular role of private family foundations as conduits for charitable contributions by the wealthy (Andreoni, 2006). ${ }^{3}$ Family foundations are created when individuals irrevocably set aside assets for eventual donation to charity and register with the IRS. The donor obtains the same tax benefits as if the assets had been transferred immediately to charity, while the foundation trustees retain them, invest them, exercise their voting rights, and must give them away at an average rate of 5\% per year. This bundle of immediate tax benefits and continuing control rights appeals to many donors, especially top executives of public companies who usually hold large amounts of appreciated equity in their own firms. Most family foundations in the sample, which are invariably controlled by the CEO and his family members as trustees, retain their donors' stock gifts for long periods rather than diversifying their assets, as would generally be required if trustees followed the prudent man rule of investment management.

The results of this paper extend the large managerial incentive literatures on stock compensation, insider trading, and corporate governance, while also illuminating issues related to income tax compliance (surveyed by Slemrod, 2007), and the economics of philanthropy (surveyed by Andreoni, 2006). Little evidence exists about the use of charitable contributions as a means of tax evasion apart from Slemrod (1989), which analyzes IRS tax audits from 1982. The data for that paper and other studies generally comes from large, anonymous samples of tax returns provided by the IRS, because accurate information about annual income and deductions can be nearly impossible to obtain directly from panels of individual taxpayers (Slemrod, 2007).

\footnotetext{
${ }^{3}$ Based upon IRS data, in 2004 the U.S. had 31,347 active family foundations with \$209 billion in assets. These figures were $28 \%$ and $6 \%$ higher, respectively, than the totals for 2000 . Donors contributed $\$ 9$ billion to family foundations in 2004, while the foundations gave away $\$ 12$ billion to charity. See The Foundation Center, "Key Facts on Family Foundations," January 2006, available at www.foundationcenter.org.
} 
In contrast, this study uses a dataset developed from public sources in which the identity of each individual is transparent, allowing for a range of tests not possible in earlier studies.

The remainder of this paper is organized as follows. Section II describes the regulatory framework for insiders' stock gifts in the areas of disclosure, income taxation, and insider trading. Section III reviews the sample selection for this study. Section IV analyzes the structure of CEOs' family foundations and the stock returns subsequent to their receipt of major stock gifts from donor CEOs. Section V concludes.

\section{Gifts of stock by company executives}

In giving away part of their wealth, executives respond to a wide range of motives (Auten, Clotfelter, and Schmalbeck, 2000). In addition to the psychic value of altruism, some donors seek public recognition both for themselves (Harbaugh, 1988) and their companies. ${ }^{4}$ Other donors use charitable contributions to achieve membership in elite social circles such as prestigious non-profit boards, which may provide not only public visibility but also access to lucrative business relationships..$^{5}$ More prosaically, philanthropic decisions also depend upon

\footnotetext{
${ }^{4}$ A signal example of such recognition occurred in 2005 when Bill and Melinda Gates were named Time magazine's Persons of the Year - an accolade generally reserved for presidents, popes, and other world leaders - for pledging tens of billions of dollars of Gates' Microsoft wealth to charitable causes such as better public health in the underdeveloped world. Ted Turner has made massive personal donations to the United Nations and used his corporation's resources to underwrite events such as the Goodwill Games, reportedly in pursuit of a Nobel Peace Prize that has yet to be awarded to him. For reports of Turner's use of philanthropy to court favorable publicity, see Sallie Hofmeister, "Turner Takes Lead in His New Race of Giving," Los Angeles Times, September 20, 1997, A1; Stephen Glass, "Gift of the Magnate," The New Republic, January 26, 1998, 20 ("The most plausible explanation, however, has more to do with glory than money: Turner wants to win a Nobel Peace Prize.”); Christopher Caldwell, "U. N.

Believable," The Weekly Standard, October 6, 1997, 12 ("Sources close to Turner's thinking say he hopes to win the Nobel Peace Prize and has actively sought for years to drum up a nomination.").

${ }^{5}$ See Monica Langley, "Even CEOs Sweat Out Carnegie Hall Tryouts, For the Board, That Is -- Once In, It's a Schmooze-Fest for Megadeal-Makers," The Wall Street Journal, July 30, 1998, A1. ("Since taking over as chairman in 1991, [Sanford] Weill . . . saw director slots as a way to flatter financial heavyweights and then tap into their personal and corporate bank accounts. . . The chance to rub elbows with fellow titans, and launch a few deals between arpeggios, is
} 
income tax incentives, estate planning considerations, disclosure requirements, and even aspects of corporate voting and control.

While finance research has closely studied how CEOs dispose of stock via sale (insider trading), exchange (mergers and acquisitions), and intergenerational bequest (family business groups), our knowledge about CEOs' stock gifts is limited to two recent working papers by Johnson and Moorman (2005) and Jung and Park (2007). Johnson and Moorman (2005) study a large sample of stock gifts by CEOs of U.S. companies between 1989 and 2003. Consistent with the results below, the authors find evidence of opportunistic gift timing near local stock price maximum points, suggesting that donor CEOs use private information to increase personal income tax benefits. They do not, however, identify the recipients of individual gifts, study the role of family foundations, or consider the hypothesis that some gifts might be fraudulently backdated. Jung and Park (2007) study transfers of stock by controlling shareholders of South Korean companies to other family members. In Korea such transfers create gift tax liability based upon the average value of the shares over a certain time interval around the gift. The paper's results suggest that companies depress their stock prices around the dates of these transfers by disclosing bad news and withholding good news from the market in order to reduce the donor CEOs' gift taxes.

\section{A. SEC reporting requirements for stock gifts}

Corporate officers, directors, and 10\% shareholders must publicly report all acquisitions and dispositions of stock, including gifts. Since the Sarbanes-Oxley Act became effective in 
August 2002, the SEC has required disclosures of open market sales and purchases on Form 4 within two business days. Older, more lenient disclosure rules continue to apply to "bona fide gifts" of stock, however. Gifts may be reported by insiders on Form 5 instead of Form 4, and the filing deadline occurs 45 days after the end of the company's fiscal year. I find that about $46 \%$ of the insiders making gifts in my sample choose voluntarily to comply with the practice for reporting open market sales, as they disclose their gifts to the SEC no more than two trading days after the transfer date (often these prompt gift disclosures are paired with other filings by the same insider, such as a simultaneous open market sale). The remaining $54 \%$ of donors take longer to disclose their gifts, some of them filing more than one year after the transfer date. The mean filing delay for gifts in the overall sample is 46 trading days (standard deviation 118 days), while the median is 4 trading days. Since June 30, 2003, the SEC has required all Form 4 and Form 5 filings to be made electronically, and these records are available for public retrieval on the SEC's EDGAR database. Prior to mid 2003 the majority of Form 4 and Form 5 filings were made in hard copy.

Basic aggregate data about executives' stock gifts can be obtained from the Thomson Financial insider trading database, which compiles Form 4 and Form 5 SEC filings by individual company insiders. Data for 2006 from the Thomson database indicate that gifts represent a major category of equity dispositions; during 2006 CEOs sold approximately $\$ 16.5$ billion worth of shares on the open market, sold another $\$ 12.1$ billion back to their companies, made gifts of about $\$ 8.8$ billion, and disposed of roughly $\$ 6.8$ billion of shares through other means. ${ }^{6}$ As

\footnotetext{
${ }^{6}$ These calculations require merging records from Thomson Financial with CRSP data for the closing stock prices of each company on each gift date. Throughout this paper I use the closing stock price on the gift date as a measure of each gift's value at the time of donation, although for tax purposes the IRS requires use of the average of the intra-day high and low prices.
} 
discussed further below, much of the aggregate reported total of stock gifts are not necessarily charitable contributions, but rather transfers to family trust funds, limited partnerships, or other entities for the benefit of an insider or his relatives.

\section{B. Income tax benefits of stock gifts}

Personal income tax regulations offer two attractive benefits to donors who make charitable gifts of stock. The fair market value of the gift is deductible from the donor's taxable income, indirectly reducing his overall tax owed. In addition, the donor escapes the capital gains tax that he would otherwise owe on the appreciation of the stock above the price he originally paid to acquire it; this tax would have eventually been paid if the donor had sold the shares instead of donating them.

The value of these tax benefits depends upon the financial circumstances of each donor. It is all but impossible to ascertain the original cost basis of the shares donated by a corporate insider, so the value of the insider's exemption from capital gains tax may be anywhere from zero to $15 \%$ of the value of the gift, since $15 \%$ is the long-term marginal capital gains tax rate today for most individuals. For the charitable contribution deduction, generally a donor receives

\footnotetext{
Aggregates from the Thomson database should not be considered comprehensive or authoritative, because the database contains a certain number of duplicate, erroneous, or incomplete records, and occasionally transactions that appear in other sources are omitted from the Thomson database entirely. Often these problems arise due to idiosyncracies of SEC reporting requirements or incomplete compliance by executives (some CEOs, for instance, list their title only as "chairman" or merely "director"; others leave required fields blank). Some filings are made by executives as late as several years after the legal reporting deadline, meaning that the totals listed above will likely increase in the future. CEOs who sell shares back to their firms often do so to pay the exercise prices or income tax withholding associated with stock options. The "other" category of CEO dispositions is dominated by share exchanges in mergers. The data are extremely skewed, and aggregates in each category can vary materially from year to year; for instance, $60 \%$ of the 2006 gifts are accounted for by just three CEO donors: Sheldon Adelson ( $\$ 2.0$ billion), Warren Buffett (\$1.9 billion), and Herbert \& Marion Sandler ( $\$ 1.3$ billion). Similar outlier observations occur periodically in the other categories.
} 
a tax benefit equal to the value of the gift times the marginal personal income tax rate. ${ }^{7}$ Most CEO-donors are probably subject to the top bracket of the Alternative Minimum Tax, meaning that their marginal tax rate is $28 \%$ plus any charitable deduction available from state personal income taxes. For example, a donor subject to New York state income tax plus the federal AMT would recognize tax benefits equal to about one-third of the face value of a charitable stock donation, plus the benefit of permanently avoiding the capital gains tax on the donated shares.

\section{Stock gifts and insider trading law}

Under the Securities and Exchange Act of 1934, corporate insiders face two broad areas of potential insider trading liability: the short-swing profit prohibition of Section 16(b), and the anti-fraud prohibition of Rule 10b-5. Short-swing profit rules bar corporate insiders from acquiring a security and then disposing of it at a higher price (or vice versa) within any interval shorter than six months. Rule 10b-5 prohibits insider trading on the basis of material, non-public information "in connection with the purchase or sale of any security." For these laws to apply to stock gifts, a donation would have to be deemed a "sale" of securities. While a gift might seem intrinsically different from a sale, the 1934 Act defines "sale" quite broadly: "The terms 'sale' and 'sell' each include any contract to sell or otherwise dispose of [securities]" (emphasis added).

For short-swing profit liability, current law provides an insider trading exemption for

\footnotetext{
${ }^{7}$ A number of qualifications apply. For instance, for gifts of appreciated stock no donor may take charitable donation deductions in excess of $20 \%$ of their Adjusted Gross Income in any one year, although excess unrealized deductions may be carried forward and used to shelter income in future years. Certain phase-outs can also apply to charitable contribution deductions, though these are capped at a percentage of income and probably do not apply at the margin for high-income donors; these phase-outs are being repealed in stages between 2006 and 2010 . See Auten et al. (2000) for a more complete discussion.
} 
"bona fide gifts." "However, no parallel exemption exists for anti-fraud liability. Therefore, an executive who makes a charitable gift and realizes a large tax benefit could potentially violate Rule 10b-5 if the company issues adverse news that drives its stock price lower shortly afterward. However, to date nobody appears ever to have been charged by the SEC with a Rule 10b-5 violation for making an untimely gift of stock, ${ }^{9}$ so the federal courts have not considered the issue directly.

For charitable gifts of stock to be treated as "sales" that trigger anti-fraud insider trading liability, case law indicates a three-part test: (1) whether a change of ownership occurs, (2) whether the donor receives consideration of pecuniary value, and (3) whether such treatment would be consistent with the remedial purposes of the 1934 Act. In addition, the donor must act with scienter, meaning an intent to deceive, manipulate, or defraud See Sulcoski (1989, pp. 614 et. seq.). Of these requirements, the second, that the donor receive valuable consideration, would seem to be the most problematic in connection with a gift. However, a line of cases has held that

\footnotetext{
${ }^{8}$ SEC Rule 16b-5(a) was amended in 1991 to codify federal caselaw that had previously protected gifts from short-swing profit liability. In proposing the amendment the SEC staff wrote, "Bona fide gifts present less likelihood for opportunities for abuse [compared to open market sales]." See "Ownership Reports and Trading By Officers, Directors and Principal Stockholders," Release Nos. 34-26333; 35-24768; IC-16669,1988 SEC Lexis 2380 (December 2, 1988). The short-swing profit gift exemption originated in Truncale v. Blumberg, 80 F.Supp 387 (S.D.N.Y. 1948). The chief executive of Universal Pictures Co. was sued by shareholders after receiving company warrants as part of his compensation and then donating those warrants to charity within six months. The plaintiff shareholders argued that the charitable donation represented a "sale," for which the executive received a "profit" equal to the value of his income tax deduction. The court ruled otherwise, stating, "By no stretch of the imagination, however, can a gift to charity or indeed to anyone else when made in good faith and without pretense or subterfuge, be considered a sale or anything in the nature of a sale. It is the very antithesis of a sale ..." 80 F.Supp 387, 391. See also Shaw v. Dreyfus, 172 F. 2d 140 (2d Cir., 1949) and Lewis v. Adler, 331 F. Supp. 1258 (S.D.N.Y., 1971).

${ }^{9}$ Private parties have the right to file enforcement actions under Rule 10b-5, but insider trading cases are invariably initiated by the SEC because the counter-party in an open market sale cannot be identified. In the aftermath of an adversely timed charitable stock gift, however, one could imagine the charity suing the donor under Rule 10b-5 if the recipient had relied upon the stock's fair market value when donated. Such litigation by a charity would likely have a chilling effect upon future donations. If the CEO tipped off the charity to sell the shares immediately after the donation, a clear-cut case of Rule 10b-5 liability would arise for both parties in connection with the sale (Wang and Steinberg, 2006, $\S 5: 2.8[\mathrm{E}]$ ).
} 
the income tax deductions received by a donor of stock may represent a pecuniary benefit under the federal securities laws. If a donor executive had adverse private information and made a gift of shares before the stock price dropped, the donor could potentially realize a tax deduction greater in value than the subsequent worth of the stock, an outcome that surely would contravene the anti-fraud purposes of the 1934 Act.

\section{Sample description}

Table I outlines the sample selection process, which I discuss in detail in this section.

To study stock gifts by top corporate executives, I search the Thomson Financial insider trading database that is compiled from insiders' Form 4 and Form 5 SEC filings. I retrieve all dispositions by way of gift $($ trancode $=\mathrm{G}$ ) made by persons who list one of their job titles (rolecode) as either Chief Executive Officer or Chairman of the Board. I include observations with the Chairman title because many CEOs hold multiple titles in their firms but do not list all of them on their SEC filings. ${ }^{10}$ A large number of Chairmen are also former CEOs, and the shares they donate to charity were often received as part of their CEO compensation.

Because my data collection strategy requires inspecting the original copies of all Form 4 and Form 5 stock gift reports, I include all observations reported since June 30, 2003, the date on which the SEC began requiring electronic posting of Form 4 and Form 5 on the SEC's EDGAR Internet portal. Prior to this date electronic filings of these documents were sparse, although about one-fifth of executives appear to have begun filing electronically on a voluntary basis after

\footnotetext{
${ }^{10}$ Warren Buffett of Berkshire Hathaway and Maurice Greenberg of American International Group are two CEOs who consistently identify themselves only as Chairman of the Board. Other CEOs are erratic in listing their titles, sometimes identifying themselves as the CEO and sometimes as Chairman, Director, President, or some combination of these.
} 
Sarbanes-Oxley became effective in August 2002 (I do not use these earlier observations because sample selection bias might apply to them). Prior to August 2002 almost no Form 4 or Form 5 filings are posted on EDGAR. I exclude observations that Thomson designates as problematic and unable to be "cleansed" due to missing or inconsistent data. I drop a small number of gifts involving securities other than common stock, such as preferred stock or warrants. I drop all gifts occurring after December 31, 2005, a cutoff necessary so that the SEC data can be merged with information from another source, private foundations' IRS Form 990PF filings. These IRS filings appear on two Internet databases maintained by Guidestar.org and The Foundation Center, but posting occurs with lags so that many foundations' filings for the year 2006 are still unavailable.

Most insider gift disclosures report the gift date and number of shares donated but not the stock's market price at the time of donation, so the value of each gift is usually not clear from the Thomson database. To ascertain each gift's value I merge records from Thomson with gift date closing stock prices obtained from CRSP, excluding about 950 observations for which no public stock prices are available. ${ }^{11}$ If a gift is made on a weekend or holiday, I value it using the closing stock price for the previous trading day. After dropping a small handful of observations with

\footnotetext{
${ }^{11}$ This merge is not easy, because the Thomson database indexes observations by CUSIPs, some of which are missing, outdated, or incomplete for certain companies, including some firms that are quite well known and clearly belong in the sample. I use a utility from the Wharton Research Data System to map Thomson CUSIPs to CRSP PERM numbers. When I cannot obtain a CRSP stock price by this method, I map Thomson observations to CRSP using company names, requiring a very close concordance between names for a match to be valid. Ultimately I drop 706 observations for companies that appear on Thomson but not on CRSP; many of these are probably closely held firms whose CUSIPs are linked to debt rather than equity securities, or small public firms with penny stocks traded in the pink sheets. I drop an additional 250 observations representing gifts that occur outside the range of dates over which the stock has been publicly traded; these are generally donations of pre-IPO or post-delisting shares.
} 
data problems, ${ }^{12}$ I have records for 9,611 stock gifts by chairmen and CEOs over the two and a half year interval studied. These gifts are associated with transfers of $\$ 18.6$ billion worth of common stock. To keep data collection manageable, I drop gifts worth less than $\$ 1$ million, representing 8,598 observations, or $89 \%$ of the sample by count but just $\$ 1.1$ billion in aggregate value, or $6 \%$ of the sample by dollar value. ${ }^{13}$ I am left with a final sample of 1,013 major gifts worth $\$ 17.5$ billion.

To learn more about these gifts, I retrieve from EDGAR the Form 4 or Form 5 associated with each observation with a value above $\$ 1$ million. Executives' SEC filings sometimes identify the entity receiving a gift or include footnotes providing further details. The SEC also requires each executive to disaggregate his beneficial ownership by reporting shares held by each legal entity, such as trust funds or limited partnerships, in which he holds a beneficial interest. By reading the Form 4 or Form 5 filing for each of the 1,013 gifts, I am able to identify a large majority (by dollar value) of major CEO stock "gifts" as transfers from the CEO to other legal entities that he also controls for the benefit of himself or his immediate family. In these cases the SEC filing will usually show a decrease in the CEO's personal direct ownership offset by an identical increase in the ownership of an entity such as a family trust fund or a limited partnership, or perhaps a transfer in ownership directly from the CEO to his spouse or a minor child. These transactions, which have various motives related to tax and estate planning,

\footnotetext{
12 These problem observations are mostly duplicates that result either from the same gift being reported by multiple persons (such as a husband and wife who each serve as company officers), or the same gift being reported twice to the SEC due to an amendment of the original filing. In addition, a few observations are inaccurate due to data entry errors by Thomson, and two observations are dropped because the associated SEC filing does not appear on EDGAR.

${ }^{13}$ About two-thirds of the smaller gifts are for amounts greater than $\$ 1,000$ but less than $\$ 100,000$. Some gifts are truly small; the CEO of Alcoa donated two shares of stock in one case, while the CEO of Coca Cola donated one share in another. The smallest gift reported to the SEC, for one share of a small cap company, had a value of $\$ 5.16$.
} 
represent 351 observations and $\$ 14.5$ billion in dollar value, about $35 \%$ of the sample

observations and $82 \%$ of the value transferred.

The remaining observations represent 662 cases in which CEOs or Chairmen make stock gifts to external recipients beyond their own families, transferring approximately $\$ 2.9$ billion worth of shares over the two and a half year sample period. I ascertain which of these gifts go to family foundations established by the CEO by searching two Internet databases of foundations' IRS filings maintained by Guidestar.org and The Foundation Center. I identify about a fourth of the gifts - 150 observations representing $\$ 670$ million of stock - as gifts made by CEOs to their own family foundations. The matching process involves determining whether a CEO is a trustee of a private foundation (Guidestar provides a searchable database of foundation trustees and officers for this purpose), and then retrieving the foundation's Form 990-PF to see whether it reports a stock gift from the executive that matches the date and number of shares reported on his Form 4 or Form 5 SEC filing. ${ }^{14}$ The final sample includes gifts to family foundations established by some of the most famous executives in American business, including Andrew Grove, Lawrence Ellison, and Wayne Huizenga, but also a wide range of foundations created by CEOs of less well known, smaller capitalization firms.

\footnotetext{
${ }^{14}$ In most cases the matching process is unambiguous, since CEOs tend to name their foundations after themselves and are almost always the foundation's only donors. However, certain problems arise in several cases. Some foundations' IRS filings aggregate several stock gifts by a CEO-donor into an annual total and report the date as "various." In these cases I include the SEC data for the gift in the sample unless information in the SEC and IRS filings is inconsistent. For about $30 \%$ of the observations minor differences exist between the gift date as reported by the executive to the SEC and the gift receipt date reported by the foundation to the IRS; many of these differences are just one or two days apart. Following IRS guidelines for determining the tax deduction associated with a stock gift, I use the transfer date reported to the SEC in the analysis below. The paper's results are virtually identical if the alternate gift date is used instead, but the SEC transfer date seems to be the more sensible choice because many gifts are filed with the SEC and disclosed publicly on dates earlier than the receipt dates shown in the foundations' IRS filings. I find four instances of $\$ 1$ million stock gifts by CEOs to their foundations that appear in IRS filings but not the Thomson database. I do not include these extra observations in the sample, but three of these four gifts are exceedingly well timed ahead of stock price drops, and the paper's results would strengthen if they were included.
} 
Table I's data detailing the sample selection process illustrate two striking facts about executives' major gifts of stock. First, for every dollar's worth of stock given to a charity or another external recipient, donors in the aggregate give almost five dollars to their own families, either directly or more commonly through trust funds or other devices. Dynastic impulses therefore appear to overwhelm philanthropic ones when most CEOs dispose of their shares. Second, when executives choose to make charitable donations, family foundations under their personal control receive a significant share of the largess, approximately one quarter of all external stock donations.

Figure 1 shows the seasonal pattern of CEOs' stock donations in all categories, displayed for each month between July 2003 and December 2005. A profound end-of-year clustering occurs, with December being by far the most popular month for stock gifts and November being the second most common (the pattern applies to all three subsamples of stock gifts identified above). This December clustering accords with the behavior of many taxpayers who make tax deductible charitable contributions at year-end once their entire year's tax liability becomes clear.

Figure 2 shows the cumulative net-of-market stock returns surrounding the dates of CEOs' stock gifts, for a period extending approximately six months (120 trading days) prior to the gift until six months after. Because some CEOs make multiple gifts on the same day, I use one observation per company-day, resulting in a sample of 903 observations used in the graph; the deleted observations include 15 for firms with IPOs within the six-month window prior to the gift date. Net-of-market returns for each observation equal the difference between each stock's raw daily return and the return on the CRSP equal-weighted market index. For comparison 
purposes, I also show cumulative net-of-market returns for the excluded sample of smaller gifts.

Figure 2 exhibits several clear patterns, closely resembling those found by Johnson and Moorman (2005) in their study of stock gifts during an earlier sample period of 1989-2003. CEOs tend to give away shares following run-ups in their companies' stock prices, and the gift date itself on average represents a turning point in the stock's trajectory, with company prices moving lower in the months after a gift is made. This reversal is more dramatic for larger gifts than for smaller ones, though both tend to occur after stock price run-ups. The steepness of the inverted V-shape is sensitive to the method used for calculating abnormal stock returns; if market model or Fama-French expected returns are used in place of the unadjusted market index, the pattern becomes more pronounced, while the descent of stock prices after the gift date is less dramatic (and not significantly different from zero) if the value-weighted CRSP market return is used in place of the equal-weighted market return. For all methodologies, the post-gift stock price decline over the first four weeks is greater for larger gifts compared to smaller ones at conventional significance levels. ${ }^{15}$

\section{Analysis of stock gifts to private family foundations}

\section{A. Description of family foundations in the sample}

As discussed earlier, family foundations can be easily established by registering with the

\footnotetext{
${ }^{15}$ It is difficult to identify a comparison sample of other legal insider stock dispositions that are informed by inside information and not constrained by anti-fraud regulations. One study on point is Gompers and Lerner (1998), who study distributions of shares in public companies by venture capital funds to their limited partners. That paper finds patterns of returns around the distribution date quite similar to those in my Figures 1 and 3 (see Gompers and Lerner's Figure 1 on page 2174 of their study).
} 
IRS, and their numbers have grown rapidly in recent years. ${ }^{16}$ The trustees of a family foundation - generally the donor, his spouse, and perhaps other relatives - manage its assets and exercise the associated voting rights. Foundations must operate within certain limits or face IRS excise taxes. For instance, penalties arise if a foundation does not give away $5 \%$ of its assets annually (measured using a five-year moving average formula) to other charitable organizations, or if it holds $20 \%$ or greater voting control in any business corporation.

The 150 large stock gifts identified in the sample are made by 89 individual CEOs over the 30-month sample period. Table II presents descriptive statistics about these executives and their foundations. The table includes data from the IRS Form 990-PF filed in the most recent year that a foundation received a major stock gift from each executive, so the table is based upon 89 observations, one per individual Chairman or CEO.

The median foundation in the sample is seven years old at the time of its most recent major donation and holds a median of $\$ 5.2$ million in total assets. Maximum values are far higher, as the oldest foundation was established 42 years ago and the largest holds more than $\$ 189$ million in assets. The median gift size is $\$ 2.9$ million, with a mean of $\$ 5.7$ million and maximum of $\$ 52.1$ million. The median foundation gives away $4 \%$ of its assets each year, and the rate of distribution to outside charities is well below the intake of new donations.

Foundations tend to follow a life cycle in which their early years exhibit a buildup of assets and relatively low rate of distribution. The right two columns of the table show medians for two subsamples: foundations less than five years old, and those aged five or more years. The median

\footnotetext{
${ }^{16}$ Many resources on family foundations are available from the Council on Foundations at www.cof.org. The IRS posts general guidelines for foundations at www.irs.gov/charities/foundations, while historical Form 990-PF aggregate data on their growth, assets, and donations can be downloaded at www.irs.gov/taxstats/charitablestats.
} 
ratio of distributions to donations is just $1 \%$ for the younger foundations but $24 \%$ for the older cohort. The median ratios of distributions to total assets are $1 \%$ and $5 \%$, respectively.

CEOs who make major stock gifts to family foundations tend to be older and considerably richer than the general population of CEOs. The median CEO in the sample is 62 and has $\$ 172.8$ million of equity invested in his firm (measured as the market value of stock plus in-the-money value of options), compared to the sample medians of 56 years old and $\$ 16.1$ million of equity for all CEOs listed on ExecuComp during the 2003-05 period. A significant number are company founders who control large blocks of stock in their firms. The median CEO in the sample has placed about $4 \%$ of his shareholdings in the family foundation. In a few cases CEOs or their family members collect small annual fees for their service as foundation trustees or officers. ${ }^{17}$

Because of donors' tax advantages related to avoiding capital gains liability, foundations in the sample receive most of their contributions in the form of shares in CEOs' companies, although some CEOs do contribute cash or other property from time to time. Data indicate that these foundations sell the donated shares very slowly. Foundations hold a median of $58 \%$ of their assets in the donor-CEO's company's stock, a fraction that is not meaningfully different in the subsamples of younger and older foundations (63\% vs. 55\%). ${ }^{18}$ A variety of statistics

\footnotetext{
${ }^{17}$ According to IRS Form 990-PF filings, John J. Schiff Jr. of Cincinnati Financial Corp., a man with a fortune exceeding half a billion dollars, since 2005 has received $\$ 30,000$ annually from the assets of the John J. \& Mary R. Schiff Foundation for serving as its Chairman, augmenting the $\$ 2$ million+ annual compensation he receives from his company. Identical payments are made to his brother and sister for serving as trustees. The fee was previously $\$ 7,500$ per year before being raised to $\$ 12,000$ in 2001 and $\$ 15,000$ in 2003.

${ }^{18}$ In an exceptional recent case, the Weill Family Foundation created by former Citigroup Chairman and CEO Sanford Weill agreed to invest in new equity issued by Citigroup in January 2008, after losses in subprime mortgage securities threatened the bank's capital adequacy. See the company's press release, "Citi Announces Key Actions to Enhance Capital Base," January 15, 2008. While many foundations receive gifts of shares in their donors' companies, in my reviews of hundreds of IRS Form 990-PF filings I found no other record of a foundation ever making a purchase of such equity, as it would only compound the lack of diversification that most family foundations exhibit.
} 
indicate that a foundation's tendency to hold the shares of the donor CEO's firm increases with the size of the CEO's personal ownership in the company. For instance, seven CEOs in the sample have ownership stakes exceeding one billion dollars, and their foundations' allocation of assets to their respectve companies' stock are $99 \%, 98 \%, 98 \%, 83 \%, 65 \%$, and $49 \%$, with one missing value. The overall sample correlation between the dollar value of a CEO's ownership and the percentage of his foundation's holdings in the company's shares is $+0.17 .{ }^{19}$

The high concentration of CEOs' private foundation assets in their donors' own company stocks seems to contradict modern investment teaching about the importance of diversification as a means of risk reduction. Diversification of charitable endowment funds is required under most circumstances by the Uniform Prudent Management of Institutional Funds Act, the model code enacted by numerous U.S. states as the legal standard for charitable trustees' investment policies. Section 3 of the Act states that "A [charitable] institution shall diversify the investments of an institutional fund unless the institution reasonably determines that, because of special circumstances, the purposes of the institution are better served without diversification." Commentary accompanying the Act goes on to state that "A decision not to diversify must be

\footnotetext{
While most CEOs' foundations concentrate their holdings in ordinary stocks, bonds, and cash equivalents, a few hold more exotic investments, including commodities funds (The Thomas and Stacey Siebel Foundation, started by Thomas Siebel of Siebel Systems Inc.) and emerging market sovereign debt (The Cumming Foundation, started by Ian Cumming of Leucadia National Corp.).

${ }^{19}$ Part of this pattern may be due to CEOs counting their foundations' shares as part of their personal beneficial ownership for reporting purposes. In reading numerous proxy statement ownership reports, I found that CEOs are quite inconsistent (and not always transparent) in choosing whether to include their private foundations' holdings as part of their personal beneficial ownership disclosures that are required in each annual proxy statement. I did not find clear SEC guidance on whether such ownership should be included. One could argue that if a CEO serves as his own private foundation's trustee (which is invariably the case), then the foundation's holdings should count as part of the CEO's beneficial ownership. That argument might be undercut, however, by the fact that the CEO's donation is irrevocable and can ultimately benefit only bona fide charitable organizations, and not the CEO personally.
} 
made based on the needs of the charity and not solely for the benefit of a donor." ${ }^{20}$

\section{B. Timing of major stock gifts to family foundations}

Figure 3 illustrates the behavior of company stock prices around the dates that their Chairmen or CEOs make stock gifts of at least $\$ 1$ million. The graph shows two lines: a red series for 150 observations of gifts to the executives' family foundations, and a blue series for 742 observations of gifts to all other recipients (a handful of observations are excluded for firms with IPOs within the six months prior to the gift date). Apart from gifts to family foundations, no meaningful difference exists in the return patterns around intra-family gifts and gifts to other external recipients, so these categories are consolidated in the blue series for clarity of display. Cumulative returns are shown on a net-of-market basis with the CRSP equal weighted market index subtracted from the raw stock return.

A comparison of the two series in Figure 3 shows several patterns. Stock donations occur after run-ups of close to $5 \%$ over the six months prior to the recorded gift date; these runups are nearly identical across the two subsamples and accelerate in the weeks immediately before the reported gift date. After this date, both series exhibit negative returns, but the decline is far steeper in the red series of gifts to family foundations. After six months the red and blue series converge to approximately the same cumulative post-gift return. The difference between the two series, then, rests in the much steeper drop that occurs in the first several weeks after the

\footnotetext{
${ }^{20}$ Uniform Prudent Management of Institutional Funds Act (2006), approved by the National Conference of Commissioners on Uniform State Laws, July 7-14, 2006, as successor to the Uniform Management of Institutional Funds Act (1972). The UPMIFA has been enacted in 14 states so far and is under legislative consideration in approximately 20 others. See www.nccusl.org. Whether a private foundation should sell the shares of a donor who contributes his own company's stock is discussed in Luis M. Viceira and Helen H. Tung, "Investment Policy at the Hewlett Foundation (2005)," Harvard Business School case 9-205-126.
} 
family foundation gifts. After 20 trading days the difference between the two series equals about 2.2 percentage points, significant below the $1 \%$ level, but after 60 trading days the difference narrows enough so that it is no longer statistically significant at conventional levels.

Table III presents greater detail about the cumulative abnormal returns following CEOs' stock gifts to family foundations. The table presents five-day and 20-day CARs calculated eight different ways as a check on the robustness of the paper's results. The table indicates that these firms underperform the market by about $1 \%$ within the first week after a large CEO stock donation to a family foundation, and by $2 \%$ to $3 \%$, depending on the method used, within four weeks or 20 trading days. The magnitude of these price declines is far larger than typical stock price movements after insiders' dispositions through open market sales. Brochet (2008), in a recent comprehensive study of thousands of top managers' sales during a similar time period, finds five-day abnormal stock price declines of $-0.19 \%$ (mean) and $-0.26 \%$ (median) after CEO stock sales, with little further movement after this initial drop. A related study by Jeng, Metrick and Zeckhauser (2003) finds no evidence of abnormal stock price declines after insider sales.

The stock price declines I find after family foundation gifts do not appear to be due to news of the gifts themselves. Many gifts are not disclosed via SEC filings for weeks or even months after the actual gift date. An event study using the filing date as the event date obtains a negative two-day CAR of about $-0.5 \%$, significant at the $5 \%$ level. However, this abnormal return is much lower in magnitude than the drops reported in Figure 3 and Table III, and it is likely due in part to other negative news about the firm that the donor may know before selecting the gift date. Interestingly, filings with longer delays lead to more negative market reactions when disclosed; for the subsample of family foundation gifts reported to the SEC 20 or more 
days after the gift date (about one-third of the sample), the two-day CAR is about $-1.0 \%$, significant at the 5\% level. These negative market reactions are consistent with shareholders inferring that a CEO who chooses to donate shares likely holds adverse, non-public news about his firm.

How large are the potential financial gains to managers who strategically time their charitable gifts? Data in Figure 3 and Table III indicate that stock prices drop close to 3\% soon after CEOs make stock gifts to their family foundations. The tax benefits to a typical CEO from capital gains avoidance plus charitable deductions are probably about one-third of the market value of donated stock, meaning that on average, the CEO's tax savings equal approximately $1 \%$ of the market value of such a stock gift. For the median gift of about $\$ 3$ million reported in Table II, this tax savings would imply a gain to the donor CEO of about $\$ 30,000$.

However, not all CEOs strategically time their charitable stock gifts. Data in Table III suggest that company stock prices rise faster than the market following about $40 \%$ of CEO stock donations to family foundations and fall after about $60 \%$. If no strategic timing of gifts occurred, this distribution should be symmetric, with the number of stocks outperforming the market equal to the number underperforming. This implies that about one in five major stock gifts to family foundations are strategically timed (the difference between $60 \%$ and $40 \%$ ). If the average $3 \%$ stock decline following all charitable stock gifts is attributed solely to the one-fifth of donations that may be opportunistically timed, then the average decline for these stocks would be about $15 \%$, net of market. The tax savings to the donor CEOs of these gifts would be one-third of this amount, equal to $5 \%$ of the gift's face value, worth $\$ 150,000$ for the median gift. Given the absence (or perhaps non-existence) or legal consequences for manipulating charitable gift dates, 
it may not be surprising to see a minority of CEO donors taking these actions to obtain six-figure personal tax savings.

\section{Why are CEOs' stock gifts followed by negative abnormal returns?}

When insiders' stock transactions are followed by unusual movements in their stocks' prices, research has traditionally attributed the pattern to exploitation of inside information. For stock gifts followed by a share price drops, one would conjecture that managers were aware of impending bad news to be released by their firms and accelerated their donations in order to obtain larger personal income tax deductions. An alternative explanation, suggested by recent research into the timing of executive stock option awards, is that charitable gifts may be documented retroactively, with the gift dates backdated by the companies and recipient charities so that donor-executives may increase their tax deductions. The post-gift date stock price declines shown in Figure 3 and Table III are consistent with either explanation, so I conduct further tests to try to distinguish between them.

The first research into executive stock option award timing by Yermack (1997) looked closely at the coordination of option awards and quarterly earnings announcements by companies. Earnings announcements are excellent news disclosures to examine, because their nearly universal schedule (all but a few firms announce earnings every three months) renders them free of sample selection bias, and because earnings news is almost always considered material information by investors. Yermack (1997) found that executive stock option awards are far more likely to occur before favorable earnings announcements and after negative announcements rather than vice-versa. These patterns later acquired the labels "springloading" 
and "bullet dodging" in the popular jargon of option timing.

Figure IV shows the distribution of Chairmen and CEOs' major stock gifts relative to the dates of quarterly earnings announcements with data aggregated on a weekly basis. Data are sorted into three groups, for intra-family transfers, gifts to family foundations, and gifts to all other outside sources. The intra-family transfers, which do not have tax consequences related to their dates, appear to be timed uniformly across different weeks with no regard for the schedule of earnings announcements. The latter two groups, each of which will usually trigger income tax deductions, appear to take close account of the earnings calendar. Far fewer stock gifts than usual occur just before earnings releases, and an unusually large number occur just afterwards.

This distribution of gift dates suggests that, even though insider trading laws do not apply to gifts, CEO donors may comply voluntarily with these laws and not make stock gifts when they would be unable to sell shares. Company compliance policies on stock gifts might also parallel those for open market sales and forbid gifts just before earnings releases (Bettis, Coles, and Lemmon, 2000). However, a closer look at the stock gifts just before and just after earnings announcements undermines this hypothesis, as shown by data in Table IV. Among the 150 major stock gifts to family foundations, five occur in the one-week period immediately preceding an earnings announcement, while 18 occur in the one-week period beginning on the earnings date and continuing for four additional trading days. Without manipulation of gift dates, one would not expect any difference in the earnings announcements that occur either immediately before or immediately after gifts. I look at the two-day raw stock price movements on the earnings announcement day and subsequent day, since only the raw price affects the donor's tax benefits. Among the five donations for which an earnings announcement is closely 
preceded by a stock gift, four companies' prices drop on the earnings news, with a mean loss of $3.47 \%$ (t-statistic 1.95). Donating just before a stock price drop would be the mirror-image analogue to the "springloading" of an executive stock option award. Among the earnings announcements that take place on the gift date or just before, company stock prices rise in 15 out of 18 cases, with a mean gain of $+5.54 \%$ (t-statistic 4.27 ) - a variant on "bullet dodging." The difference in sample means, $9.01 \%$, is significant well below the $1 \%$ level. These data about earnings announcements suggest that CEOs do take advance information about earnings releases into account when choosing the timing of stock gifts to their own family foundations. It gives no indication one way or the other about whether these gifts might be backdated.

Evidence for the backdating of executive stock options developed by Lie (2005) and Heron and Lie (2007) rests upon three empirical patterns: (1) option awards that occur in regular calendar patterns ("scheduled awards"), such as the same week every year, are not as favorably timed as those that occur at unexpected times ("unscheduled awards"); (2) the favorable timing of option awards tends to improve with the amount of time that an executive takes to disclose the award to the SEC; and (3) awards tend to be timed not only with the firm's abnormal movement relative to the market, but also with movements in the underlying market index. I explore each of these patterns with respect to CEOs' family foundation stock gifts, estimating regression models with the dependent variables equal to the cumulative raw stock return and cumulative net-of-market stock return, both measured over the 20 days following each stock gift by a CEO.

As shown by Figure 1, a large number of CEOs' stock gifts occur in December, a pattern caused by many individuals who wait until year-end to determine their charitable contributions once they have full knowledge of their annual taxable income (one might also say that many 
people procrastinate until the end of the tax year and donate only when faced with the imminent postponment of the deduction). I conjecture that gifts during the other 11 calendar months, the analogue of unscheduled executive stock option awards, are more likely to be strategically timed or backdated. Therefore, I estimate separate regression models for two subsamples of gifts, those made in December and those in the remaining 11 months.

Explanatory variables in the regressions include dummy variables for gifts to family foundations and gifts to other non-family recipients, since these gifts generally provide tax benefits of varying size; the log of the face value of each award; and the number of days elapsed between the reported gift date and its SEC filing. To test the backdating hypothesis for various subsamples of gifts, I include two interaction terms between the reporting lag variable and indicators for family foundation gifts and other non-family gifts.

Coefficient estimates in Table $\mathrm{V}$ provide evidence consistent with the backdating of stock gifts by CEOs to their own family foundations, at least for gifts made outside the month of December. The interaction term between the family foundation indicator variable and the reporting lag is negative and significant in the left two columns. This implies that nonDecember family foundation gifts tend to be better timed when CEOs take longer to disclose these gifts in SEC filings; a longer reporting delay gives the reporting executive a longer window over which to look back and select a favorable purported gift date. I also find that, holding the reporting lag constant, family foundation gifts are better timed than other stock gifts, and larger gifts are better timed than smaller gifts, for the 11-month non-December subsample. For gifts made in December, none of the regressor variables has a significant coefficient estimate, implying donors engage in little or no backdating or exploitation of inside information when 
making gifts near the end of the year.

I re-estimate the models in Table $\mathrm{V}$ using the market index return as the dependent variable (the output is equivalent to the difference of the estimates in columns one minus two and three minus four). No evidence emerges of coordination between the timing of gifts and movements in the overall market. The absence of significant estimates for these variables means that the evidence for backdating of CEOs' gifts to family foundations is not as comprehensive as the evidence for backdating of executive stock option awards.

\section{Discussion and conclusions}

This paper studies large gifts of stock by Chairmen and CEOs of public companies to their own private family foundations. I find that CEOs make these charitable stock gifts just before sharp drops in their share prices, a pattern that increases the value of their personal income tax deductions arising from the gifts. I explore circumstantial evidence of whether the favorable timing of CEOs' stock gifts occurs because of access to inside information or retroactive backdating. Some tests support both of these explanations. Together these results illuminate a surprising mix of motives by corporate executives who make large charitable contributions: while seeking to subsidize good works in society, they simultaneously follow aggressive tax evasion strategies.

The results of this study have implications for several issues at the intersection of securities regulation, tax policy, and the economics of philanthropy. One might see the data presented above as justification for the SEC and the federal courts to reconsider their indifference to whether stock gifts should be regulated similarly to open market stock sales, with 
prompt disclosure, blackout periods, and application of the "disclose or abstain" doctrine to prevent the abuse of inside information by corporate executives. The results of this paper indicate that two groups may be systematically harmed by opportunistically timed stock gifts: taxpayers and charities, and the government has a longstanding interest in protecting each of these large constituencies. However, one might wonder whether CEOs would donate as much if insider trading laws were enforced to curb strategic gift timing. A lengthy literature has estimated the role of tax subsidies in encouraging charitable giving (Feldstein and Taylor, 1976; O'Neil, Steinberg and Thompson, 1996). These studies generally conclude that donations to charity rise when the availability of valuable tax deductions increases, especially for wealthy taxpayers. The ability to time stock gifts strategically can be viewed as a type of tax subsidy. Tax and securities regulators authorities may be aware of donors' propensity to choose opportunistic dates on which to give appreciated stock to charity, but they may tolerate this behavior if it creates social benefits through higher charitable giving.

Data about private family foundations suggest reasons for the IRS to scrutinize their asset holdings and rates of giving. Most foundations in my sample diversify very little and donate their assets to outside charities at modest rates. In some cases the immediate tax benefits to a donor CEO who contributes appreciated stock may easily exceed the discounted present value of charitable donations made by the foundation over time. One consultant to non-profit firms told The Wall Street Journal in 1997 that, "For rich people who've made a killing in the stock market lately, the ultimate status symbol is creating a foundation with your name on it," adding, "The majority of these so-called charitable foundations [are] motivated more for avoiding taxes and 
supporting pet projects than helping society.",21

${ }^{21}$ Monica Langley, “All in the Family: A Tax Break Prompts Millionaires' Mad Dash to Create Foundations," The Wall Street Journal, January 27, 1997, A1. 


\section{Bibliography}

Andreoni, James, 2006, "Philanthropy," in Serge-Christophe Kolm and Jean Mercier Ythier eds., Handbook of the Economics of Giving, Altruism, and Reciprocity 1 (Oxford: North-Holland).

Auten, Gerald E., Charles T. Clotfelter, and Richard L. Schmalbeck, 2000, "Taxes and philanthropy among the wealthy,"in Joel B. Slemrod ed., Does Atlas Shrug? The Economic Consequences of Taxing the Rich (Cambridge: Harvard University Press), 392-424.

Bettis, J. Carr, Jeffrey L. Coles, and Michael L. Lemmon, 2000, "Corporate policies restricting trading by insiders," Journal of Financial Economics 57, 191-220.

Brochet, Francois, 2008, "Information content of insider trades: Before and after the SarbanesOxley Act," unpublished manuscript, Harvard Business School.

Feldstein, Martin, and Amy Taylor, 1976, "The income tax and charitable contributions," Econometrica 44, 1201-1222.

Gompers, Paul, and Josh Lerner, 1998, "Venture capital distributions: Short-run and long-run reactions," Journal of Finance 53, 2161-2183.

Harbaugh, William T., 1988, “The prestige motive for making charitable transfers," American Economic Review 88:2, 277-282.

Heron, Randall A., and Erik Lie, 2007, "Does backdating explain the stock price pattern around executive stock option grants?” Journal of Financial Economics 83, 271-295.

Jeng, Leslie A., Andrew Metrick, and Richard Zeckhauser, 2003, "Estimating the returns to insider trading: A performance-evaluation perspective," Review of Economics and Statistics 85, 453-471.

Johnson, Shane A., and Theodore C. Moorman, 2005, "Charitable CEOs? An Analysis of Stock Returns Surrounding Gifts of Stock," unpublished manuscript, Texas A\&M University.

Jung, Woon-Oh, and Sung Ook Park, 2007, "Do controlling shareholders in Korea attempt to influence stock prices when making a stock gift?" unpublished manuscript, Seoul National University (available at ssrn.com/abstract $=1014541$ ).

Lie, Erik, 2005, "On the timing of CEO stock option awards," Management Science 51, 802812.

O’Neil, Cherie J., Richard S. Steinberg, and G. Rodney Thompson, "Reassessing the tax-favored status of the charitable deduction for gifts of appreciated assets," National Tax Journal 49, 215 233. 
Slemrod, Joel, 1989, "Are estimated tax elasticities really just tax evasion elasticities? The case of charitable contributions," Review of Economics and Statistics 71, 517-522.

Speiller, William M., 1980, "The favored tax treatment of purchasers of art," Columbia Law Review 80:2, 214-266.

Sulcoski, Carol J., "Looking a gift of stock in the mouth: Donative transfers and Rule 10b-5," Michigan Law Review 88, 604-634 (1989).

Slemrod, Joel, 2007, "Cheating ourselves: The economics of tax evasion," Journal of Economic Perspectives 21, 25-48.

Wang, William K.S., and Marc I. Steinberg, 2006, Insider Trading (New York: Practising Law Institute).

Yermack, David, 1997, "Good timing: CEO stock option awards and company news announcements, "Journal of Finance 52, 449-476. 


\section{Table I \\ Sample description}

The table describes the process of identifying a sample of major stock gifts by Chairmen and CEOs of public companies. Candidate observations are extracted from the Thomson Financial insider trading database compiled from executives' Form 4 and Form 5 SEC stock transfer filings made between June 30, 2003, and December 31, 2005. Daily closing stock price data from CRSP is used to determine the value of each gift. For gifts worth $\$ 1$ million or more, recipients are identified when possible by reading the original Form 4 and Form 5 documents posted on the SEC's EDGAR website, and by reading IRS Form 990-PF filings by CEOs' private family foundations posted on websites maintained by Guidestar.org and The Foundation Center.

Obs. Dollar value Mean gift

Total gifts listed on database

$10,567 \quad \$ 18.48$ billion $\$ 1.7$ million

Executives' companies not listed on CRSP

Gifts during pre-IPO or post-delisting periods

Less than $\$ 1$ million value

n.a.

n.a.

Sample of large gifts with valid data

$(8,598)$

n.a.

n.a.

Gifts for personal benefit of CEO and family

To trust funds, limited partnerships, LLCs, etc.

To relatives directly (non-dependents)

Gifts to charity and other external recipients

To private family foundations

To charitable family trusts

To unknown recipients

\begin{tabular}{|c|c|c|}
\hline $\begin{array}{r}(313) \\
(38)\end{array}$ & $\begin{array}{r}(\$ 14.21 \text { billion) } \\
\text { ( } \$ 0.26 \text { billion) }\end{array}$ & $\begin{array}{l}\$ 45.4 \text { million } \\
\$ 6.7 \text { million }\end{array}$ \\
\hline 662 & $\$ 2.93$ billion & $\$ 4.4$ million \\
\hline 150 & $\$ 0.67$ billion & $\$ 4.5$ million \\
\hline 10 & $\$ 0.03$ billion & $\$ 3.3$ million \\
\hline 502 & $\$ 2.43$ billion & $\$ 4.8$ million \\
\hline
\end{tabular}


Table II

Descriptive statistics about family foundations receiving large CEO stock gifts

Descriptive statistics about private family foundations established and controlled by Chairmen and CEOs of 89 U.S. public companies. The sample includes private foundations that received gifts of $\$ 1$ million or more of their sponsor's company stock one or more times between June 30, 2003 and December 31, 2005; the 89 foundations received a total of 150 such gifts during this period. One observation is shown per foundation, with data tabulated in the year of the most recent $\$ 1$ million stock gift. Financial data is transcribed from IRS Form 990-PF filings by each foundation. The age of each foundation is measured as the difference between the reporting year and one year prior to the date of its IRS tax exemption ruling, as reported by Guidestar.org.

\begin{tabular}{|c|c|c|c|c|c|c|c|c|}
\hline & Obs. & $\underline{\text { Mean }}$ & Std.Dev. & Min. & $\underline{\text { Max. }}$ & $\begin{array}{l}\frac{\text { Median }}{\text { for }} \\
\underline{\text { entire }} \\
\underline{\text { sample }}\end{array}$ & $\begin{array}{l}\frac{\text { Median for }}{\text { foundations }} \\
\frac{\text { less than five }}{\text { years old }}\end{array}$ & $\frac{\underline{\text { Median for }}}{\text { foundations }} \frac{\text { five or more }}{\text { years old }}$ \\
\hline Age of CEO's foundation & 89 & 8.1 years & 7.8 & 0 & 42 & 7 & 1 & 9 \\
\hline Total assets of foundation & 89 & $\$ 17.6 \mathrm{~mm}$ & $\$ 32.5$ & $\$ 0.8$ & $\$ 189.1$ & $\$ 5.2$ & $\$ 4.3$ & $\$ 7.4$ \\
\hline Annual gifts to foundation & 88 & $\$ 5.7 \mathrm{~mm}$ & $\$ 7.6$ & $\$ 1.0$ & $\$ 52.1$ & $\$ 2.9$ & $\$ 2.3$ & $\$ 3.0$ \\
\hline Annual grants by foundation & 89 & $\$ 2.0 \mathrm{~mm}$ & $\$ 6.3$ & $\$ 0$ & $\$ 52.5$ & $\$ 0.4$ & $\$ 0.05$ & $\$ 0.8$ \\
\hline Grants / gifts & 88 & 0.31 & 0.51 & 0 & 3.86 & 0.12 & 0.01 & 0.24 \\
\hline Grants / (assets+grants) & 89 & 0.11 & 0.17 & 0 & 0.98 & 0.04 & 0.01 & 0.05 \\
\hline Age of CEO & 89 & 61.4 years & 9.6 & 39 & 85 & 62 & 60 & 63 \\
\hline CEO stock ownership & 89 & $\$ 473.6 \mathrm{~mm}$ & $\$ 1,108.9$ & $\$ 1.7$ & $\$ 8,376.9$ & $\$ 172.8$ & $\$ 150.0$ & $\$ 173.3$ \\
\hline CEO stock held by foundation & 74 & $\$ 9.7 \mathrm{~mm}$ & $\$ 23.1$ & $\$ 0$ & $\$ 168.1$ & $\$ 3.0$ & $\$ 1.4$ & $\$ 3.4$ \\
\hline $\begin{array}{l}\text { CEO foundation's assets/ } \\
\text { CEO stock ownership }\end{array}$ & 89 & 0.14 & 0.44 & 0.002 & 3.73 & 0.04 & 0.04 & 0.08 \\
\hline $\begin{array}{l}\text { Fraction of CEO foundation's } \\
\text { assets held in CEO's stock }\end{array}$ & 74 & 0.55 & 0.40 & 0 & 1.00 & 0.58 & 0.63 & 0.55 \\
\hline
\end{tabular}




\section{Table III}

\section{Cumulative abnormal stock returns around dates of large CEO stock gifts}

Cumulative abnormal returns (CARs) around 150 dates on which the CEO or Chairman of a public company donates at least $\$ 1$ million of personally owned company shares to his own private family foundation. The top half of the table shows CARs calculated for the five-day period following the reported date of the stock gift, while the bottom half shows CARs calculated over the 20-day period subsequent to the reported gift date. CARs are calculated according to eight different methods, and each cell of the table reports the mean CAR, the test statistic for the null hypothesis that the CAR equals zero, and the percentage of CAR observations that have negative values. CAR calculations exclude one observations for a firm that had its IPO shortly prior to the event date. Market model and Fama-French expected returns use a 252 day parameter estimation period that stops 252 days before the reported gift date. Expected returns for matched portfolios are obtained from Kenneth French's website. The sample is based upon executives' Form 4 and Form 5 stock transfer reports filed with the SEC as reported on the Thomson Financial insider trading database, cross-checked against Form 990-PF filings with the IRS by each donors' private family foundations.

Model of expected returns:

Benchmark portfolio weighting

$\operatorname{CAR}\left[\mathrm{t}_{+1}, \mathrm{t}_{+5}\right]$

$\mathrm{Mean}$
$\mathrm{Z}$ or t-statistic
$\%$ negative

$\operatorname{CAR}\left[\mathrm{t}_{+1}, \mathrm{t}_{+20}\right]$

Mean

$\mathrm{Z}$ or t-statistic

$\%$ negative

\section{Market model}

four factor model

weighted weighted

$\begin{array}{cc}-1.18 \% & -1.12 \% \\ -2.35^{\mathrm{c}} & -2.63^{\mathbf{b}} \\ 61.1 \% & 58.4 \% \\ & \\ & \\ -3.12 \% & -3.25 \% \\ -2.79^{\mathbf{b}} & -3.29^{\mathbf{a}} \\ 59.1 \% & 61.7 \%\end{array}$
weighted

$-3.18 \%$

$-3.86^{\mathrm{a}}$
Fama-French

\section{Net-of-market}

Equal Value

weighted

$\begin{array}{ll}-0.96 \% & -1.06 \% \\ -2.34^{\mathbf{c}} & -2.64^{\mathbf{b}} \\ 58.4 \% & 58.4 \%\end{array}$

$-3.54 \%$

$-4.41^{\mathrm{a}}$

$59.1 \%$
Matched book-to-market and size decile portfolios

Significant at $1 \%\left(\left(^{\mathbf{a}}\right), 5 \%\left(\left(^{\mathbf{b}}\right)\right.\right.$, and $10 \%\left({ }^{\mathbf{c}}\right)$ levels. 


\section{Table IV}

Two-day stock returns following earnings announcements close to major CEO stock gifts

Two-day stock price reactions following company quarterly earnings announcements for subsamples of announcements that occur close to the dates of major CEO stock gifts to family foundations. The first line of the table shows data for gifts that are dated within the five trading days prior to an earnings announcement. The second line is based upon gifts made on the earnings announcement day or the four subsequent days. Gift dates are obtained from SEC Form 4 and Form 5 stock transfer records by company executives, and earnings announcement dates are obtained from IBES.

\section{Timing of gift}

$[\mathrm{t}-5, \mathrm{t}-1]$ before announcement

$[\mathrm{t} 0, \mathrm{t}+4]$ after announcement

Difference

\section{Positive Negative \\ earnings earnings}

Number

5

18

15 $\underline{\text { Mean }} \underline{\text { t-statistic }}$

4

$-3.47 \%$

3

\begin{tabular}{ll}
$5.54 \%$ & 4.27 \\
\hline $9.01 \%$ & 4.09
\end{tabular}




\section{Table V}

\section{Regression model of cumulative returns following large CEO stock gifts}

Ordinary least squares estimates for models of cumulative stock returns over the 20 days following gifts of stock by Chairmen and CEOs of U.S. public companies. In the first and third columns the dependent variable equals the raw stock return of the CEO's company. The second and fourth columns use the market adjusted return as the dependent variable, equal to difference between the raw stock return and the CRSP equal weighted market index. t-statistics based on robust standard errors appear below each coefficient estimate. The sample is identified from SEC Form 4 and Form 5 stock transfer reports compiled by the Thomson Financial insider trading database. The reporting lag is the number of market trading days between the reported gift date and the SEC filing date. Gifts to family foundations and other external recipients are identified from the texts of SEC filings by executives and IRS filings by executives' private family foundations. The value of each stock donation is calculated using the CRSP closing stock price on the reported gift date. When an executive makes multiple gifts on one day, only one observation appears in the regression, and the minimum reporting lag is used.

\begin{tabular}{|c|c|c|c|c|}
\hline Month of gift: & Januar & ovember & & nber \\
\hline Stock return dependent variable: & Raw & Raw-Market & Raw & Raw-Market \\
\hline Intercept & $\begin{array}{l}0.120^{\mathrm{a}} \\
(3.60)\end{array}$ & $\begin{array}{l}0.110^{\mathrm{a}} \\
(3.54)\end{array}$ & $\begin{array}{l}0.008 \\
(0.19)\end{array}$ & $\begin{array}{c}-0.073^{\mathrm{c}} \\
(1.94)\end{array}$ \\
\hline $\begin{array}{l}\text { Log (donation value) } \\
\times 10^{-2}\end{array}$ & $\begin{array}{l}-1.095^{\mathrm{a}} \\
(2.99)\end{array}$ & $\begin{array}{l}-1.195^{\mathrm{a}} \\
(3.58)\end{array}$ & $\begin{array}{r}-0.079 \\
(0.18)\end{array}$ & $\begin{array}{l}0.383 \\
(0.95)\end{array}$ \\
\hline Family foundation gift indicator & $\begin{array}{c}-0.027^{\mathbf{b}} \\
(2.09)\end{array}$ & $\begin{array}{c}-0.030^{\mathbf{b}} \\
(2.55)\end{array}$ & $\begin{array}{l}0.005 \\
(0.38)\end{array}$ & $\begin{array}{l}0.009 \\
(0.66)\end{array}$ \\
\hline Other external gift indicator & $\begin{array}{l}-0.014 \\
(1.44)\end{array}$ & $\begin{array}{l}-0.015 \\
(1.62)\end{array}$ & $\begin{array}{l}0.001 \\
(0.05)\end{array}$ & $\begin{array}{l}0.008 \\
(0.63)\end{array}$ \\
\hline $\begin{array}{l}\text { Reporting lag (days) } \\
\times 10^{-4}\end{array}$ & $\begin{array}{l}0.082 \\
(0.26)\end{array}$ & $\begin{array}{l}-0.098 \\
(0.33)\end{array}$ & $\begin{array}{l}1.507 \\
(0.63)\end{array}$ & $\begin{array}{l}2.703 \\
(1.18)\end{array}$ \\
\hline $\begin{array}{l}\text { Reporting lag } \times \text { family foundation indicator } \\
\times 10^{-4}\end{array}$ & $\begin{array}{l}-2.995^{\mathrm{c}} \\
(1.77)\end{array}$ & $\begin{array}{l}-2.832^{\mathrm{c}} \\
(1.93)\end{array}$ & $\begin{array}{l}-0.246 \\
(0.08)\end{array}$ & $\begin{array}{l}-1.116 \\
(0.41)\end{array}$ \\
\hline $\begin{array}{l}\text { Reporting lag } \mathrm{x} \text { other external gift indicator } \\
\mathrm{x} 10^{-4}\end{array}$ & $\begin{array}{l}-0.459 \\
(0.73)\end{array}$ & $\begin{array}{l}-0.279 \\
(0.47)\end{array}$ & $\begin{array}{l}-0.132 \\
(0.05)\end{array}$ & $\begin{array}{r}-1.674 \\
(0.67)\end{array}$ \\
\hline $\begin{array}{l}\text { Observations } \\
\text { Adjusted R2 } \\
\text { F-statistic }\end{array}$ & $\begin{array}{c}612 \\
0.027 \\
3.81^{\mathrm{a}}\end{array}$ & $\begin{array}{c}612 \\
0.035 \\
4.67^{\mathrm{a}}\end{array}$ & $\begin{array}{c}265 \\
-0.007 \\
0.68\end{array}$ & $\begin{array}{c}265 \\
0.013 \\
1.58\end{array}$ \\
\hline
\end{tabular}

Significant at $1 \%\left({ }^{a}\right), 5 \%\left({ }^{b}\right)$, and $10 \%\left(\left(^{c}\right)\right.$ levels. 


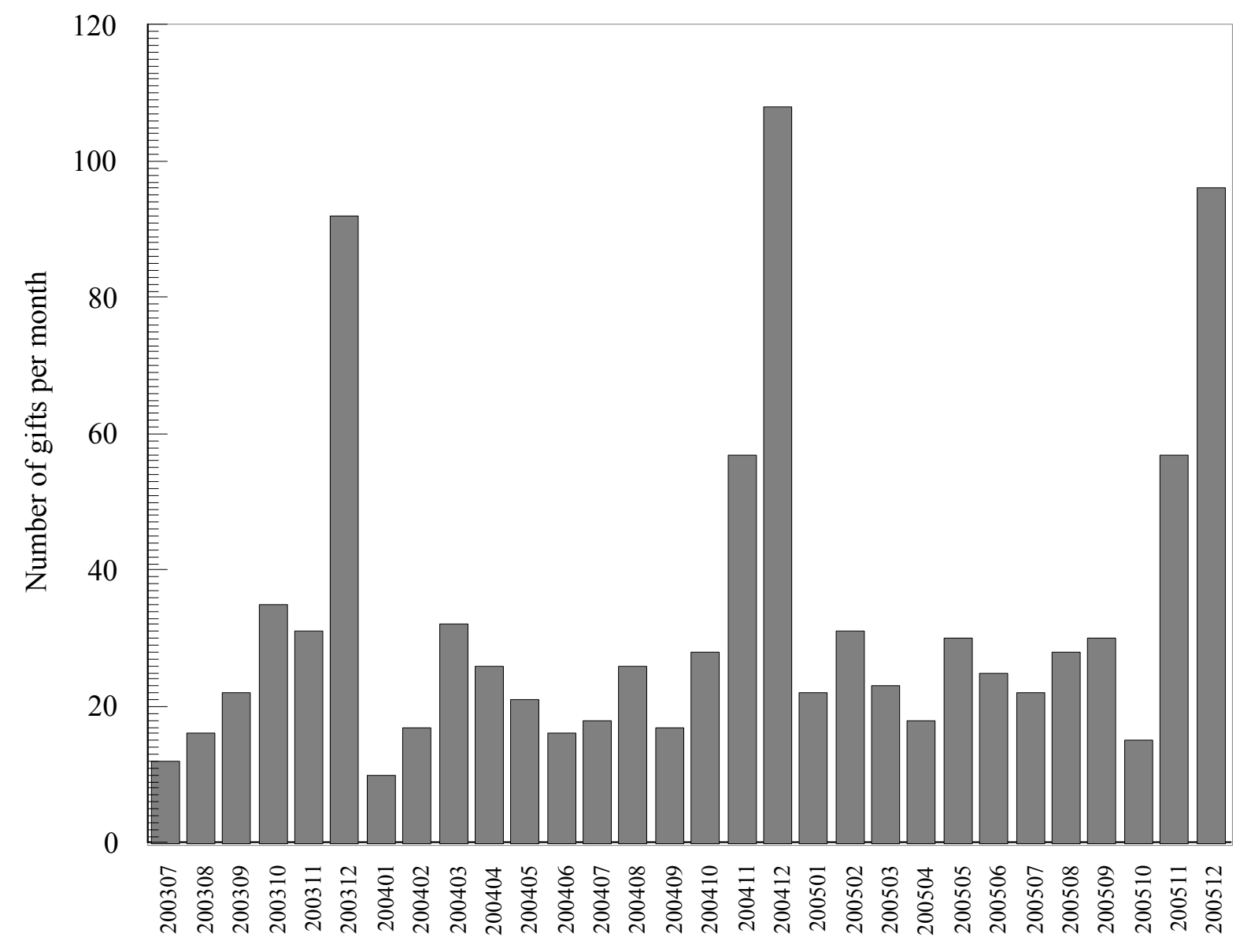

Figure 1

Seasonal pattern of CEOs' large stock gifts

The figure shows monthly data for the number of stock gifts worth at least $\$ 1$ million that are reported to the SEC by Chairmen and CEOs of public companies. The sample is compiled from SEC Form 4 and Form 5 filings reported on the Thomson Financial insider trading database between June 30, 2003, when electronic SEC filing became mandatory, and December 31, 2005. 


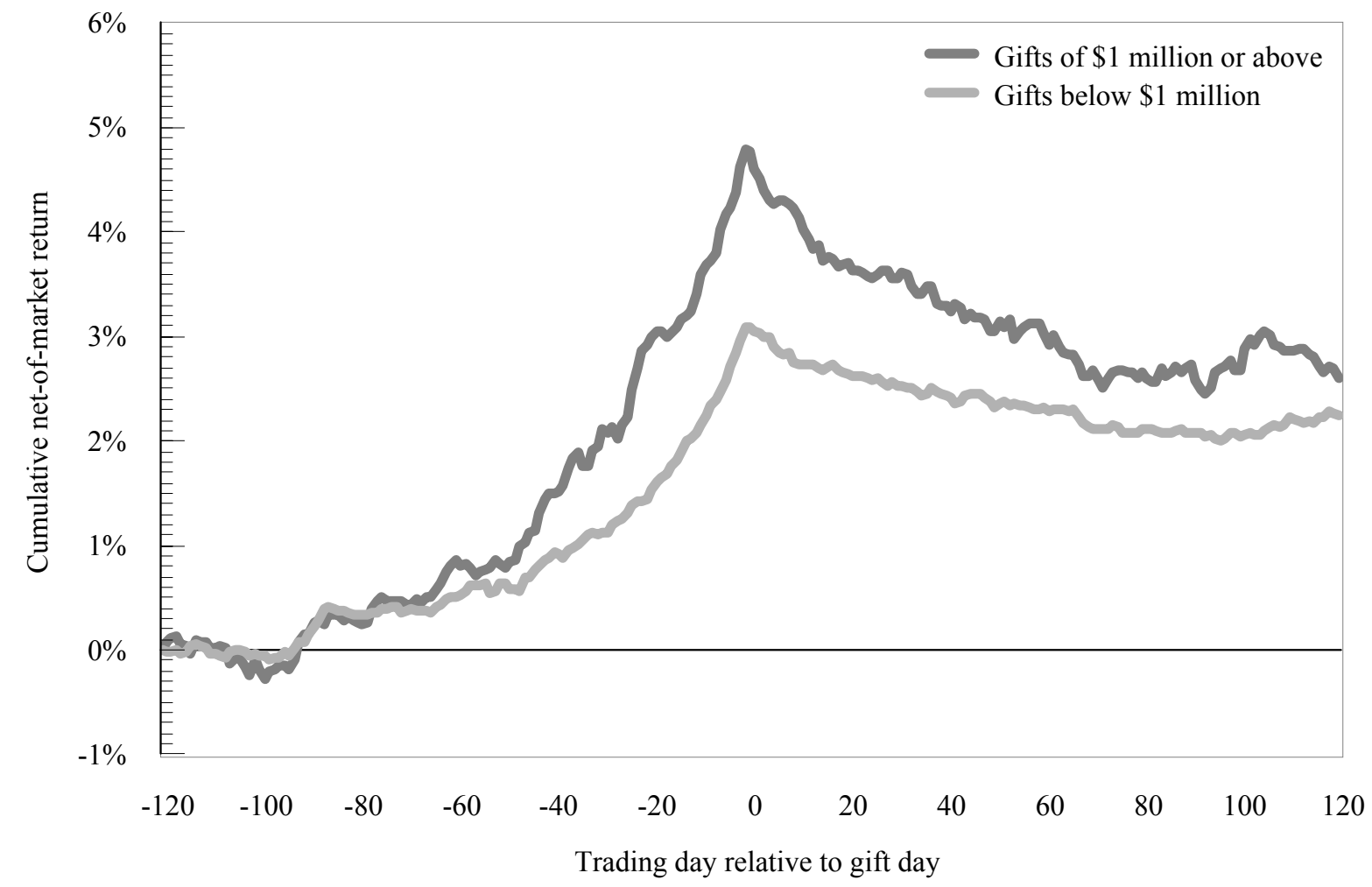

Figure 2

Shareholder returns surrounding dates of large stock gifts by top corporate executives

The chart shows cumulative net-of-market stock returns for a sample of companies whose Chairmen or CEOs make gifts of stock, with the sample partitioned into two series based upon the face value of the gifts. The sample is identified from the Thomson Financial insider trading database and includes 903 unique company-date observations for gifts of \$1 million or more, and 5,854 company-date observations for smaller gifts (only one observation is included in the tabulations when multiple gifts are made by one person on the same day). Calculations use the difference between each stock's raw return and the CRSP equal-weighted market index. 


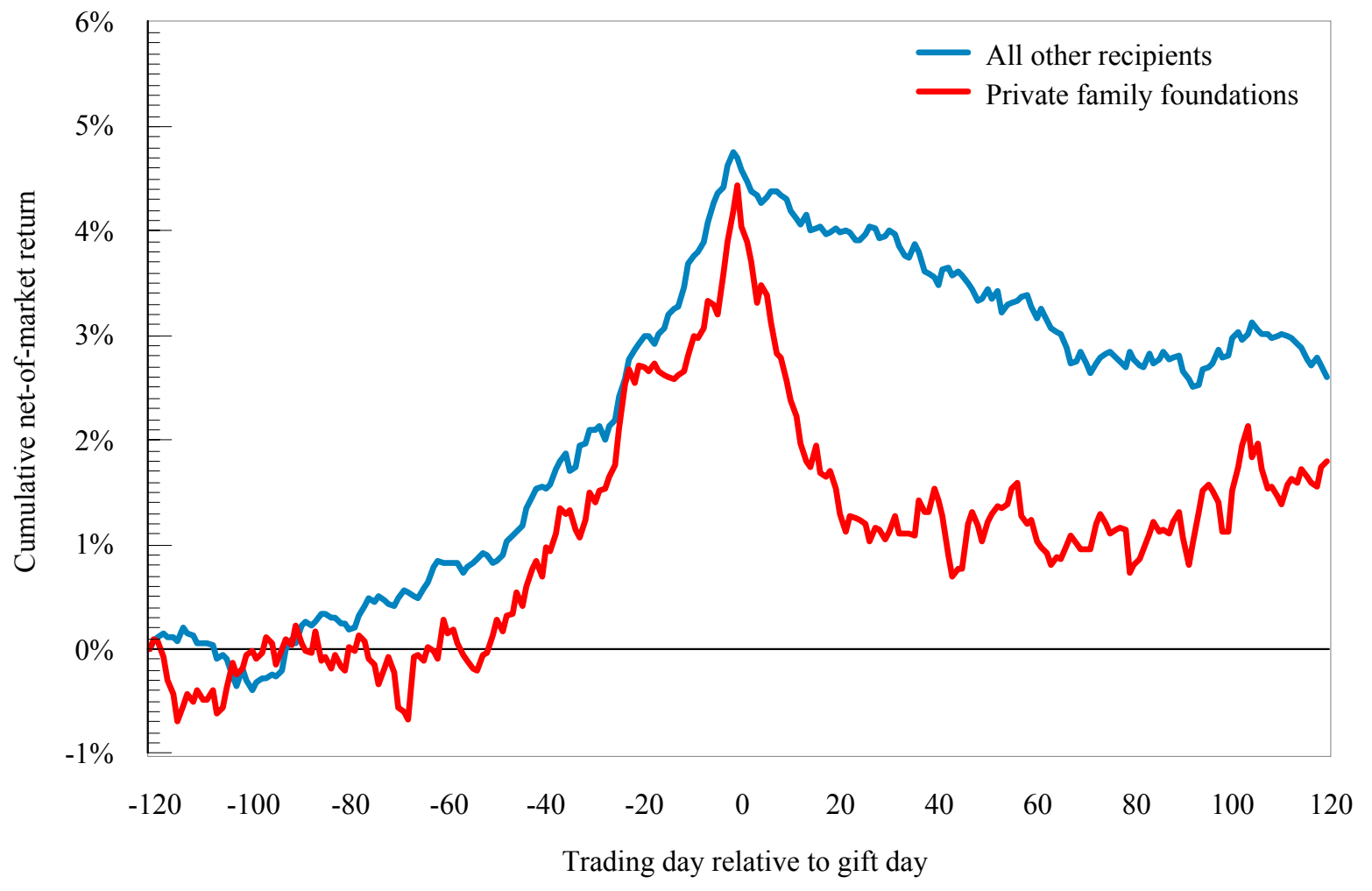

\section{Figure 3}

Shareholder returns surrounding dates of executives' stock gifts, sorted by recipient

The chart shows cumulative net-of-market stock returns for two samples of companies whose Chairmen or Chief Executives make gifts of stock worth $\$ 1$ million or more. The red series shows returns for a portfolio of 150 firms whose donors contribute stock to their own private family foundations. The blue series shows returns for 742 other firms whose donors contribute to other types of recipients. The samples are identified from the Thomson Financial insider trading database of SEC Form 4 and Form 5 stock transfer filings, and the Guidestar.org and Foundation Center databases of IRS Form 990-PF foundation filings. Only one observation per firm is included on days that a CEO makes multiple gifts. Return calculations use the difference between each stock's raw return and the CRSP equal-weighted market index. 


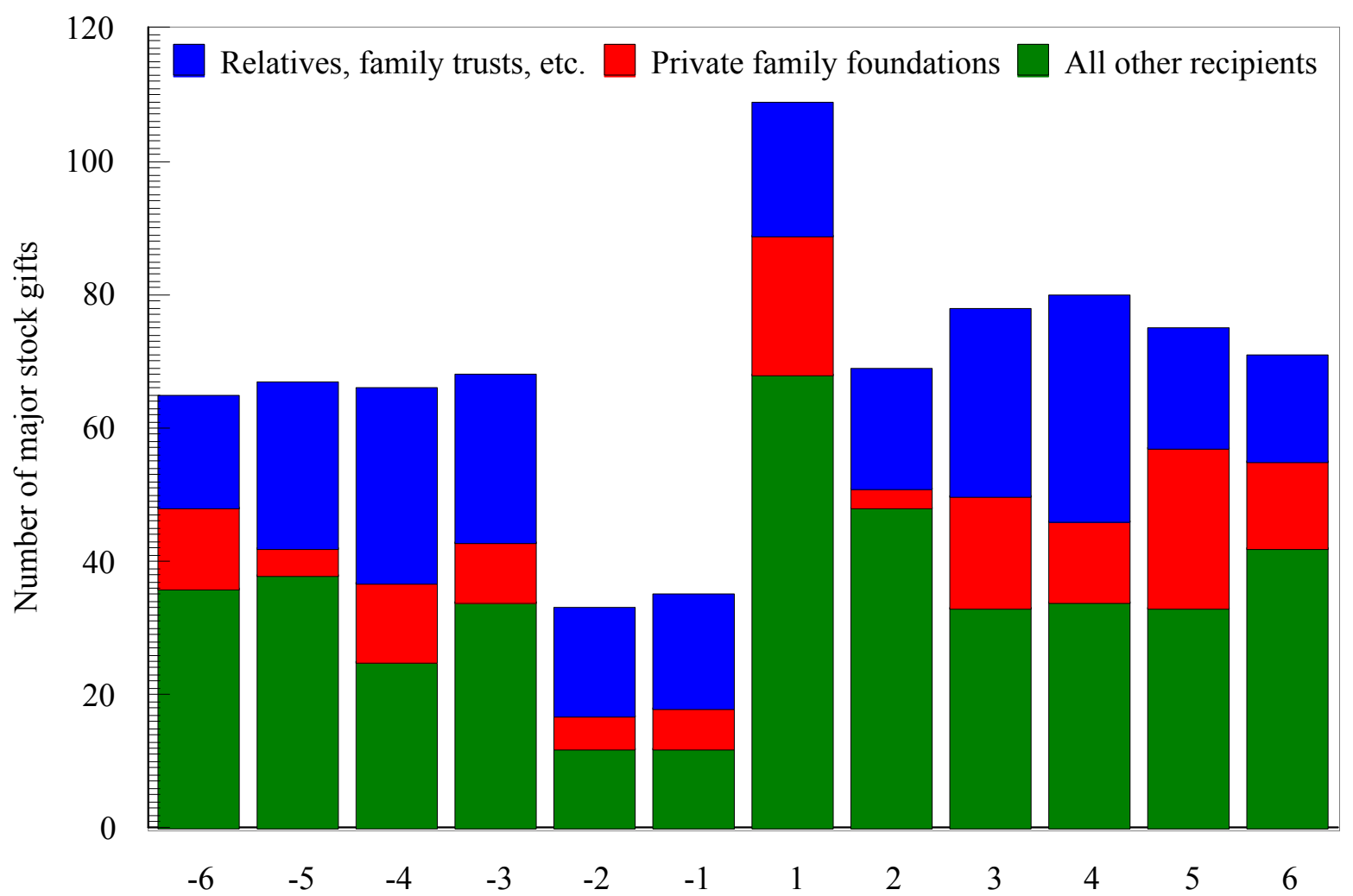

Week relative to quarterly EPS announcement

\section{Figure 4 \\ Timing of executives' major stock gifts, relative to quarterly earnings announcements}

The chart shows the distribution of the timing of gifts of stock worth $\$ 1$ million or more by Chairmen and CEOs of U.S. public companies between mid-2003 and the end of 2005. Gift dates are tabulated weekly relative to the dates of quarterly earnings announcements by the executives' firms. Gifts are shown in three categories, depending upon whether the recipient is a trust fund or similar entity for the benefit of the CEO or his family (the blue series), a private family foundation established by the CEO (the red series), or any other external recipient (the green series). The samples are identified from the Thomson Financial insider trading database of SEC Form 4 and Form 5 stock transfer filings, and the Guidestar.org and Foundation Center databases of IRS Form 990-PF foundation filings. Only one observation per firm is included on days that a CEO makes multiple gifts. Dates of quarterly earnings announcements are obtained from IBES, augmented by information from public news reports. 